\title{
Selected Element of Servant Leadership and Its Effect on Teachers' Job Satisfaction
}

\author{
Mukhlis Catio* \\ Universitas Pamulang Tangerang, Banten Province, Indonesia \\ *Corresponding Author: Mukhlis Catio, Universitas Pamulang Tangerang, Banten Province, Indonesia

\begin{abstract}
This study aimed to identify the influence of servant leadership on the change management in schools. This cross-sectional survey involved 150 secondary school teachers in Bogor, West Java Indonesia by using the questionnaire as the research instrument. The instrument employed was Servant Leadership Scale (SLS). Results showed that servant leadership contributed to the job satisfaction of teachers in schools. Thus, servant leadership should be applied and practiced by school leaders to improve the school performance.
\end{abstract}

Keywords: Servant Leadership, Change Management, Secondary School, Teachers

\section{INTRODUCTION}

To support the Indonesian Ministry of Education's aspiration to produce superior schools to develop individual potential through quality education, every school is responsible for working hard to improve its performance as well as to carry out continuous improvements in anticipating the current development. In this regard, principals at the school level are essential to plan, implement and monitor every aspect of the policy applied. Principals are managers of changes and thrusts to the task of leading change in school. As a manager at the school level, principals are the most important people who can influence the success of the school (Biare et al., 2018). Leadership is an essential part of the management activities to move the organization to create new ideas for creative and innovative organizational excellence (Mohtar \& Rajiani, 2016; Hargreaves \& Ainskaw, 2015). Without strong leadership, an effective corporate operation will not apply (Jaques, 2017). Servant leadership is a person-centered leadership approach where leaders give support to subordinates to achieve their potential fully involving the personal relationship with subordinated to understand and support their motivation (Spears \& Lawrence, 2016).

The primary mission of a school principal is to serve both the school community and society. The concept of educational leadership as service to others provides a distinctive view which draws attention to the principles of ethics and caring. It also shifts the way the management views the members of organization as they are no longer perceived as "individualistic, opportunistic, and selfserving" employees but are seen as people who care about the organization and simultaneously try to achieve personal goals in a milieu of mutual trust (Van Dierendonck, \& Patterson, 2015). This way, effective schools are signed by the servant leadership manners of their principals because these behaviors produce higher levels of teachers' job satisfaction (Tischler et al., 2016), which in turn, as Karadag et al. (2015) claims, has a positive effect on students' accomplishments. As such this study would like to analyze the effect of servant leadership to teachers' job satisfaction within the Indonesian setting.

\section{LITERATURE REVIEW}

The literature will highlight dimensions of servant leadership in making teachers be satisfied together with the aspects forming these variables.

\subsection{Servant Leadership}

In Indonesia, there has been a tendency to follow Western approaches to leadership development and training, even though it is acknowledged that the cultural setting is very contradictive (Rajiani \& Kot, 
2018; Rajiani \& Pypłacz, 2018). Servant leadership is one of the leadership approaches that have raised in studies of leadership popularized by Greenleaf (Cerit, 2009). Servant leadership is an attitude of leading others from a perspective of placing the organizational purpose, the needs of the organization, and the needs of people over the needs and desire of the leader (Woodruff, 2004). Servant leadership usually focuses on follower development with the intention of increasing follower capacity to exercise creative approaches and take on greater responsibilities at work (Stone and Patterson, 2005). Laub (2018) identified six characteristics of servant leaders: (1) valuing people (listening respectively, serving the needs of others first and believing in people); (2) developing people (providing opportunities for learning, modelling appropriate behaviour and building up others through encouragement); (3) building community (building strong relationships, working collaboratively and valuing individual differences); (4) displaying authenticity (integrity and trust, openness and accountability, and a willingness to learn from others); (5) providing leadership (envisioning the future, taking the initiative and clarifying goals); (6) sharing leadership (creating a shared vision, sharing decision making power and sharing status and privilege with all levels of the organization). Servant leadership as behaviours or leader characteristics include humility, relational power, service-orientation, follower development, encouragement of follower autonomy, altruistic calling, emotional healing, persuasive mapping, wisdom and organizational stewardship (Barbuto and Wheeler, 2006).

Although some criticisms have been pronounced, servant leadership can be used in managing educational institutions whose primary function is to develop people (Taylor et al., 2007). In servant leadership, great passion for improving individually and enhancing school development has become a priority place over all other needs. Spending the school day dealing with additional issues is ceased by boosting an environment in which individuals volunteer to give rather than a climate in which egoism is accepted, and efforts towards dealing with desired educational issues are encouraged making teacher and students can develop their potential more fully (Cerit, 2009). As such in this model, the selected elements analyzed are (1) valuing people (2) developing people and (3) building community.

\subsection{Teacher's Job Satisfaction}

Teacher job satisfaction refers to a teacher's affective relation to his or her teaching role and is a function of the perceived relationship between what one wants from teaching, and what one perceives it offers to a teacher (Zembylas and Papanastasiou, 2004). Teachers job satisfaction is influenced by several factors including the desire to help students achieve, the desire to make a difference in society, autonomy, pay, perceived support from principals, leadership and work conditions (Ghenghesh, 2016). One of these factors is the leadership behaviours of principals (Choi et al., 2016). Various studies carried out in educational settings revealed that leadership behaviours of principals affected the job satisfaction of teachers (Fackler \& Malmberg, (2016). One of the leadership styles influencing teachers' job satisfaction is servant leadership (Jing, 2019). Fung (2017) found that Laub's each of the six constructs of servant leadership positively correlated with teacher job satisfaction. Based on these results, it is assumed that servant leadership may have a positive impact on teachers' job satisfaction. Thus, the present study will attempt to test the validity of replicate results in a different country of Indonesia by selecting the specified elements relevant to Indonesian setting.

Based on the above description, the following hypothesis is formulated:

- Valuing people is positively related to a teacher's job satisfaction.

- Developing people is positively related to a teacher's job satisfaction.

- Building community is positively related to teacher's job satisfaction.

- Valuing people, developing people and building community are simultaneously related to teacher's job satisfaction.

\section{Methodology}

This research applies a survey method with the correlational approach to investigate the relationship between variables in the study using three independent variables through data gathered from questionnaires. The independent variable is valuing people $\left(\mathrm{X}_{1}\right)$, developing people $\left(\mathrm{X}_{2}\right)$, and building community $\left(\mathrm{X}_{3}\right)$, while the dependent variable is the teachers' job satisfaction (Y). The relationship among variables in the study described in Fig. 1 below: 


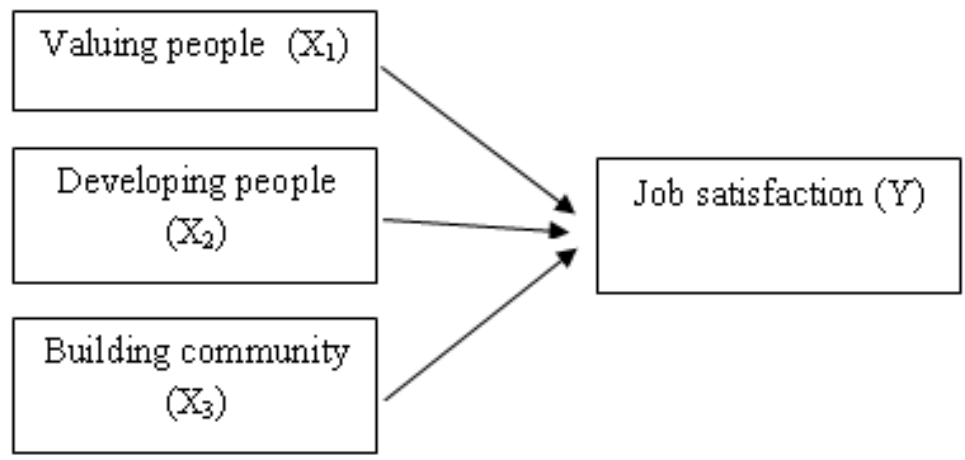

Figure1. Theoretical framework

School principal's servant leadership behaviors were measured using the items developed by Laub (2018). This scale determines the degree in which the respondents were asked to indicate the extent to which they agreed with the statement using a five-point Likert scale ranging from 1 (strongly disagree) to 5 (strongly agree). Teachers' job satisfaction was measured using Mohrman-CookeMohrman job satisfaction questionnaire (Emmanuel \& Hassan, 2015) which consisted of eight items. Participants used a five-point Likert scale to indicate their degree of satisfaction ranging from 1 (very dissatisfied) to 5 (very satisfied).

The random sampling of 150 teachers in the secondary school of Bekasi, West Java Indonesia was taken. Hypothesis testing is performed by using a regression analysis to determine the effect of one or more independent variables on the dependent variable. The linearity assumption is conducted before the further test to determine eligibility. Hypothesis testing is held at a significance level of 0.05 .

\section{RESUlt AND Discussion}

The teachers of listed schools were asked to take part in the survey by stating their opinions for different measures in servant leadership and job satisfaction. The linearity test is calculated with $F$ test. Data is linear since upon the calculation the value of each variable is above the critical value for F-test.

In the structural model, as depicted in Table 1 , valuing people $\left(\mathrm{X}_{1}\right)$ had direct positive significant influence toward teacher's job satisfaction $(Y)$ about $=0.206(t=2.968 ; \mathrm{p}<0,01)$. Developing people $\left(\mathrm{X}_{2}\right)$ had direct positive influence toward teacher's job satisfaction about $0.440(\mathrm{t}=6.668 ; \mathrm{p}<$ 0.01).Building community $\left(\mathrm{X}_{3}\right)$ had direct positive significant influence toward teacher's job satisfaction about $0.210(\mathrm{t}=3.179 ; \mathrm{p}<0.01)$ with coefficient of determination $=0.521$ (Table 2$)$.

Table1. Path coefficient of the model

\begin{tabular}{|c|c|c|c|c|c|c|}
\hline \multirow{2}{*}{\multicolumn{2}{|c|}{ Model }} & \multicolumn{2}{|c|}{ Unstandardized Coefficients } & \multirow{2}{*}{$\begin{array}{c}\text { Standardized Coefficients } \\
\text { Beta } \\
\end{array}$} & \multirow[t]{2}{*}{$\mathbf{t}$} & \multirow[t]{2}{*}{ Sig. } \\
\hline & & B & Std. Error & & & \\
\hline \multirow[t]{4}{*}{1} & (Constant) & 33,317 & 6.750 & & 4.936 & .000 \\
\hline & $\mathrm{X} 1$ & .197 & .066 & 206 & 2.968 & .003 \\
\hline & $\mathrm{X} 2$ & .415 & .062 & .440 & 6.668 & .000 \\
\hline & $\mathrm{X} 3$ & .716 & .225 & .210 & 3.179 & .002 \\
\hline
\end{tabular}

Dependent Variable: Y

Table2. Summary of structural model

\begin{tabular}{|c|c|c|c|c|}
\hline \multicolumn{5}{|c|}{ Model Summary } \\
\hline Model & R & R Square & Adjusted R Square & Std. Error of the Estimate \\
\hline 1 & $.722^{\mathrm{a}}$ & .521 & .512 & 7.98646 \\
\hline
\end{tabular}

Predictors: (Constant), X3, X2, X1

The model derives the following equation: $\hat{Y}=33,317+0.197 \mathrm{X}_{1}+0.415 \mathrm{X}_{2}+0.716 \mathrm{X}_{3}$.

Observing the value of regression coefficient from the highest to the lowest, this model confirms the selected elements of servant leadership of building community $\left(\mathrm{X}_{3}\right)$ is the most common variable in defining the teachers' job satisfaction, followed by developing people $\left(\mathrm{X}_{2}\right)$ and valuing people $\left(\mathrm{X}_{1}\right)$. Overall, like in previous research in other countries, the findings show that servant leadership plays an important role in enhancing the effectiveness of teacher's job satisfaction in schools. Based on this 
result, principals who contribute professional development of teachers may increase teachers' job satisfaction. To improve teachers' job, satisfaction principals are encouraged to develop teachers and provide an environment where teachers can easily communicate with each other. Hence, it is imperative that school leaders in Indonesia are given adequate exposure and training to enhance their servant leadership in the pursuit of teachers' job satisfaction in school. To achieve the agenda of national education transformation, the aspects of servant leadership and teachers' job satisfaction need to be taken into account accordingly.

Although there have been different approaches and research findings on leadership style toward job satisfaction, it is more likely for the teachers who have a unique culture, and servant leadership style affects job satisfaction better because teachers' attitudes affect their behavior. Thus positive attitudes are expected to result in positive behaviors. These positive behaviors will also improve the performance of teachers and bring out positive results for their school. Therefore, it is quite important for the school to be aware of the leadership style that will affect teachers' job satisfaction.

\section{CONCLUSION}

This research proved that ranks from the highest to the lowest, the elements of servant leadership: building community, developing people, and valuing people have a direct positive influence toward job satisfaction of teachers. The results of this study are limited to the opinions of teachers in Bekasi Regency where the research was conducted.

Although this study reveals the relationship between servant leadership and job satisfaction, the results display the perceptions of the teachers working in the respective school. As such, studies conducted in different places are necessary for a generalization of the results. Hence, it is recommended that research on the effects of servant leadership on job satisfaction should be carried out in a different geographic location of Indonesia.

\section{REFERENCES}

[1] Barbuto Jr, J. E., \& Wheeler, D. W. (2006). Scale development and construct clarification of servant leadership. Group \& Organization Management, 31(3), 300-326.

[2] Beare, H., Caldwell, B. J., \& Millikan, R. H. (2018). Creating an excellent school: Some new management techniques. Routledge.

[3] Cerit, Y. (2009). The effects of servant leadership behaviours of school principals on teachers' job satisfaction. Educational Management Administration \& Leadership, 37(5), 600-623.

[4] Choi, S. L., Goh, C. F., Adam, M. B. H., \& Tan, O. K. (2016). Transformational leadership, empowerment, and job satisfaction: the mediating role of employee empowerment. Human resources for health, 14(1), 73.

[5] Emmanuel, A. O., \& Hassan, Z. (2015). The effects of Transformational Leadership on Job Satisfaction: A study on four and five Star Hotels in Kuala Lumpur. International Journal of Accounting, Business and Management, 1(1), 1-14.

[6] Fackler, S., \& Malmberg, L. E. (2016). Teachers' self-efficacy in 14 OECD countries: Teacher, student group, school and leadership effects. Teaching and Teacher Education, 56, 185-195.

[7] Fung, H. (2017). The Relationship between Servant Leadership and Staff Job Satisfaction in Boarding Schools. ProQuest LLC.

[8] Ghenghesh, P. (2016). Job Satisfaction and Motivation-What Makes Teachers Tick?. Editors, 1040.

[9] Hargreaves, A., \& Ainscow, M. (2015). The top and bottom of leadership and change. Phi Delta Kappan, 97(3), 42-48.

[10] Jaques, E. (2017). Requisite organization: A total system for effective managerial organization and managerial leadership for the 21st century. Routledge.

[11] Jing, X. (2019). Servant Leadership and Job Satisfaction: A Qualitative Study in the Chinese Healthcare Context. In Servant Leadership Styles and Strategic Decision Making (pp. 106-130). IGI Global.

[12] Karadağ, E., Bektaş, F., Çoğaltay, N., \& Yalçın, M. (2015). The effect of educational leadership on students' achievement: a meta-analysis study. Asia Pacific Education Review, 16(1), 79-93.

[13] Laub, J. (2018). Leveraging Servant Leadership Power. In Leveraging the Power of Servant Leadership (pp. 255-275). Palgrave Macmillan, Cham.

[14] Mohtar, N. S., \& Rajiani, I. (2016). Conceptual Model in Using Ability and Opportunity as GHRM. International Business Management, 10(17), 3840-3846.

[15] Rajiani, I., \& Kot, S. (2018). The Prospective Consumers of the Indonesian Green Aviation Initiative for Sustainable Development in Air Transportation. Sustainability, 10(6), 1772. 
[16] Rajiani, I., and P. Pypłacz. "National culture as modality in managing the carbon economy in Southeast Asia." Polish Journal of Management Studies 18 (2018).

[17] Spears, L. C., \& Lawrence, M. (Eds.). (2016). Practicing servant-leadership: Succeeding through trust, bravery, and forgiveness. John Wiley \& Sons.

[18] Stone, A. G., \& Patterson, K. (2005, August). The history of leadership focus. In Servant Leadership Research Roundtable Proceedings.

[19] Taylor, T., Martin, B. N., Hutchinson, S., \& Jinks, M. (2007). Examination of leadership practices of principals identified as servant leaders. International journal of leadership in education, 10(4), 401-419.

[20] Tischler, L., Giambatista, R., McKeage, R., \& McCormick, D. (2016). Servant leadership and its relationships with core self-evaluation and job satisfaction. The Journal of Values-Based Leadership, 9(1), 8.

[21] van Dierendonck, D., \& Patterson, K. (2015). Compassionate love as a cornerstone of servant leadership: An integration of previous theorizing and research. Journal of Business Ethics, 128(1), 119-131.

[22] Woodruff, T. R. (2004). Executive pastors' perception of leadership and management competencies needed for local church administration (Doctoral dissertation, Thesis--Southern Baptist Theological Seminary).

[23] Zembylas, M., \& Papanastasiou, E. (2004). Job satisfaction among school teachers in Cyprus. Journal of Educational Administration, 42(3), 357-374.

Citation: Mukhlis Catio. “ Selected Element of Servant Leadership and Its Effect on Teachers' Job Satisfaction" International Journal of Managerial Studies and Research (IJMSR), vol 7, no. 2, 2019, pp. 7-11. doi: http://dx.doi.org/10.20431/2349-0349.0702002.

Copyright: () 2019 Authors. This is an open-access article distributed under the terms of the Creative Commons Attribution License, which permits unrestricted use, distribution, and reproduction in any medium, provided the original author and source are credited. 